\title{
MACROECONOMIC IMPACT OF PENSION SYSTEM UPON PRIVATE PENSION FUNDS SCHEME. EMPIRICAL EVIDENCE FROM CENTRAL AND EASTERN EUROPEAN COUNTRIES
}

\author{
Florin Cornel Dumiter* \\ "Vasile Goldiș" Western University of Arad, Romania \\ E-mail:fdumiter@yahoo.com
}

\author{
Stefania Amalia Jimon \\ "Vasile Goldiș" Western University of Arad, Romania \\ E-mail: jimonstefania@yahoo.com
}

\author{
Nicolae Balteș \\ "Lucian Blaga" University of Sibiu, Romania \\ E-mail:n_baltes@yahoo.com
}

(Received: January 2021; Accepted: March 2021; Published: May 2021)

\begin{abstract}
The significance of retirement savings and private pension funds increased in the latest decades and gathered important amounts of capitals. The purpose of this paper is to investigate the macroeconomic effects of pension systems from an investment perspective in five Central and Eastern European countries. The analyzing process regarding several underlying macroeconomic effects of pension systems started from the premises that there is a strong connection between the structure of pension systems, the national economy and the development of the financial sector. The econometric tests were processed and applied by using pool data regression models and the method Pooled Instrumental Variables (IV) Two-stage Least Squares (2SLS). The main conclusion highlights that the interest rate at deposits is correlated with the amount of incomes earned by population, inflation rate, severe material deprivation rate and the investment strategy of private pension funds.
\end{abstract}

Keywords: Pension systems; Investment funds scheme; Equities; Macroeconomic effects.

JEL Classification: J32, E43, E44

\footnotetext{
* Corresponding author: Florin Cornel Dumiter. E-mail: fdumiter@yahoo.com

Copyright (C) 2021 The Author(s). Published by VGWU Press

This is an Open Access article distributed under the terms of the Creative Commons BY 4.0 license (Creative Commons - Attribution 4.0 International - CC BY 4.0) which permits unrestricted use, distribution, and reproduction in any medium, provided the original author and source are credited.
} 
Dumiter, F.C., Jimon, S.A., Baltes, N. (2021)

Macroeconomic impact of pension system upon private pension funds scheme. Empirical evidence from Central and Eastern European countries.

\section{Introduction}

From an anthropological point of view, European social protection systems are much diversified. From the liberalized markets of the western continent to the conservative systems from former socialist countries, social and financial protection of the elderly represents an important topic of social agenda of all countries and also for many international organizations.

Social protection of the old population is mainly realized via pension systems. These aspects can be defined as a mechanism of protection against the risk of reducing or losing the capability to obtain incomes as a consequence of ageing, accidents, illnesses, or disabilities. The purpose of any pension system is to provide financial security, reduce poverty risk and keep the decent life of the population. The state, due to national autonomy and sovereignty, has the role of regulation and redistribution of national wealth, and therefore can organize and manage the social protection and pension system. However, nowadays the several developed countries implemented pension systems based on the principle of contribution, meaning that only the individuals who fulfill the minimum contributory period and reach the standard retirement age will receive the pension benefits.

Worldwide, can be identified several types of pension systems. World Bank and International Labor Organization promote a multi-pillar pension system that enables the acquirement of income for different sources in order to maintain an adequate replacement rate. Hence, according to these organizations, the national pension system should be composed of the following: a noncontributory pension system, public pension system, mandatory private pension funds and voluntary pension funds. Moreover, it is recommended a nonfinancial pillar be dedicated to provide social services for pensioners. A large share of countries implemented the multi-pillar structure, adapted at the national framework, but it can be noted the predominance of private pension funds in North American and Western European countries, and the prevalence of public pension systems in Asia, Africa, Latin America and Eastern Europe, even if the multi-pillar structure was implemented.

After 1989, Central and Eastern European countries (CEEC) passed over a process of defining and formation of national identity following European Community values, like freedom, equality, solidarity, non-discrimination and meritocracy. These countries made important reforms in order to adjust to the new socioeconomic reality characterized by reduced fertility, increased life expectancy, and extensive migration. One consequence of these demographic conditions is the decline of the activity and employment rate. This situation has a direct impact on pay-as-you-go public pension systems, which is confronted with a decrease of the incomes from mandatory social contributions, simultaneous with an increased 
Dumiter, F.C., Jimon, Ș.A., Balteș, N. (2021)

Macroeconomic impact of pension system upon private pension funds scheme. Empirical evidence from Central and Eastern European countries.

number of beneficiaries. Therefore, several reforms were taken in order to consolidate budgetary sustainability.

One direction of the reform was the privatization of the public pension system, by implementing mandatory pension funds, occupational pension funds and voluntary pension funds. These funds are financed by the contributions paid by members and are invested in financial assets, the purpose being the multiplication of resources needed at retirement. From the introduction of private pension funds in CEEC, the coverage of private pension funds increased to over $50 \%$ of the active population in Romania, Czech Republic and Poland (OECD, 2017). The assets of private pension funds reach over 12 billion USD in Slovakia and Romania, and almost 48 billion USD in Poland (OECD, 2017). Also, there was advocate personal responsibility for ensuring the incomes needed at retirement by private saving. However, personal saving is conditioned by several factors, as the amount of income, consumption expenditures and saving rate, as so as financial knowledge.

The financial flows gathered by pension systems and pension funds generated important effects both regarding the beneficiaries and other economic agents. With respect to beneficiaries, the pensions obtained offer the required income, reduce the risk of poverty and severe material deprivation, smooth consumption, increase wellbeing, health and happiness. On the other hand, the capital amount of private pension funds led to the development of investment funds and stock markets increased the usage of financial products by households and as a consequence, the financial literacy and integration enhanced.

In latest years, the personal responsibility for detaining an adequate income at retirement increased and the amount of capital carried by private pension funds of CEEC had spectacular growth. The purpose of this paper is to investigate the macroeconomic effects of pension systems from an investment perspective. Therefore, we propose an empirical study regarding the correlation between several macroeconomic indicators regarding the financial sector and social policy for five CEEC, namely: Czech Republic, Hungary, Poland, Romania and Slovakia. The main conclusion highlights that the interest rate at deposits is correlated with the amount of incomes earned by population, inflation rate, severe material deprivation rate and the investment strategy of private pension funds.

The present paper has been organized into several sections, as follows: first, it was showed the significance of pension systems and the latest developments made in CEEC regarding private savings; the second part presents the literature review regarding challenges in private saving, financial product and investment strategies; the third section introduces the research methodology and data usage in the empirical study; the fourth part is consacrated to express the empirical results and final section offers the conclusions and final discussions of the article. 
Dumiter, F.C., Jimon, S.A., Balteș, N. (2021)

Macroeconomic impact of pension system upon private pension funds scheme. Empirical evidence from Central and Eastern European countries.

\section{Literature review}

The nexus between demographic situation, labor market and public pension systems in CEEC, based on the principle of social solidarity and intergenerational redistributions are facing the risk of decreasing the budgetary resources and the increasing of pension benefits expenses, once the birth rate drops and the number of old people and their life expectancy are growing. Schneider (2009) noticed that pension system reforms in Europe don't succeed in overcoming the demographic pressure and in order to consolidate the financial sustainability of public pension budgets, Eatock (2015) highlights the importance of long-life learning, active ageing and private savings. However, the diminishing role of the state in ensuring the financial protection of the elderly raised concerns about the investments made by the population and its returns (Grech, 2014), due to the lack of financial knowledge and the improper or misuse of financial information.

OECD report regarding the financial literacy of the population of G20 countries highlights that most people, and especially women, don't have basic financial knowledge (OECD, 2017). Also, in the report of the National Bank of Romania (2018) regarding the financial stability is showed the low degree of financial inclusion of the population aged over 60 years in CEEC, especially in the case of Romania. Moreover, Mihailovs \& Kreituss (2015) find a lack of knowledge regarding pension schemes among the population of Latvia. In this regard, the study made by Anderson, Baker \& Robinson (2017) shows that saving behavior is mostly driven by perceived, not actual, financial literacy of individuals and therefore people have mistaken beliefs about financial products.

Financial literacy and financial inclusion can be increased by the competitiveness of financial institutions, which will develop more accessible financial products for their clients (Marin \& Schwabe, 2019). Several authors had studied the link between financial literacy and people behavior, concluding that highly financial literacy is related with a decreased indebtedness (Gerardi, Goette \& Meier, 2013), savings and investments in the stock market (Almenberg \& Dreber, 2015), capacity to handle unexpected expenses (Hasler, Lusardi \& Oggero, 2018). Lusardi \& Mitchell (2014) highlight that people with a higher financial knowledge are saving more for retirement and as a consequence, the poverty risk is decreasing, and economic growth is encouraged (Majid et al., 2019).

The tendency to save for retirement depends on the people's expectations for the future, Apouey (2018) showing that individuals that expect to live longer or become disabled are preparing for old age. Kurtbegu (2018) states that if the pension systems have harsh eligibility criteria, the most appropriate method for financial protection at retirement is an individual investment. Metzger (2018) studied the saving behavior in Germany and found that the possession of retirement 
Dumiter, F.C., Jimon, Ș.A., Balteș, N. (2021)

Macroeconomic impact of pension system upon private pension funds scheme. Empirical evidence from Central and Eastern European countries.

saving accounts among spouses is positively correlated, suggesting a crowding behavior relating to savings. The crowding behavior regarding retirement savings was also treated by Gerrans et al.; the authors' results showing that investment decisions are influenced by the workplace mates' behavior, especially if we are talking about the ones of the same gender (Gerrans et al., 2018).

Rey-Ares, Fernandez-Lopez, and Vivel-Bua (2018) found that the decision of privately saving for retirement is positively related to age, household income and wealth, higher levels of formal education, job situation, good health status, and long-term planning horizons. Also, Gallo, Torricelli \& van Soest (2018) found that in Italy, participation in a retirement plan is positively correlated with financial education, age and the amount of income. Income appears to be the essential factor for saving and access a retirement private scheme, Dushi et al. (2017) showing that in the US low pay workers tend to have small participation ratios to retirement plans. However, Berk et al. (2013) show that in CEEC the amount that people should save every month is determined by the asset allocation choice, not by the income level.

As a concern, the investment structure of private pension funds in CEEC, the report of OCDE regarding developments of pension markets reveals that over $60 \%$ of total assets of private pension funds of Czech Republic, Hungary, and Romania are found as bills and bonds, a share of $20 \%$ of Czechia's private pension funds represents cash and deposits and only a small share is allocated to equities. On the contrary, in Poland over $80 \%$ of the assets of private pension funds are equities, and also a share of $20 \%$ of Romanian private pension funds are allocated to equities. The same report indicates that the real investment rate of return has negative values for all five countries included in this study (OECD, 2019).

Taking into account that individuals who save for retirement are targeting a longrun period, Zeng et al. (2018) found three main factors for an optimal investment strategy of pension funds: ambiguity aversion, investment in derivatives, salary and contribution. Supplementary pensions have developed with the purpose of increasing the incomes of beneficiaries and maintain welfare at retirement. Thus, the connections between pension funds and stock markets lead to an increased sensitivity of an individual's retirement wealth to stock market returns (Gustafson, 2017). Therefore, the main causes found to be responsible for the low development of supplementary pensions, especially in CEEC are the preference for non-financial instruments, low rate of return of financial markets, low incomes of the population and lack of social partners (European Commission-Directorate-General for Employment, Social Affairs and Inclusion, 2018).

Other reasons for the reduced importance of private pension funds are identified by Wang et.al. (2016). According to the authors, the extensive reformation of pay-as- 
Dumiter, F.C., Jimon, S.A., Balteș, N. (2021)

Macroeconomic impact of pension system upon private pension funds scheme. Empirical evidence from Central and Eastern European countries.

go public pension systems towards privately managed pension funds in developing countries doesn't have the expected results due to the lack of suitability of reforms to the national socio-economic context. The shortage of reforms' feasibility made it impossible to sustain the reforms à la longue (Wang et al., 2016). The combination of large expenditure of public pension system, increased burden of the social contribution of current employees and the negative rate of return of private pension funds lead to the minimalization of mandatory private pension funds in CEEC. The next table synthesizes the main empirical studies regarding the effects of retirement savings on the financial sector and other macroeconomic topics.

Table 1 Previous empirical studies regarding personal savings and investment strategies of private pension funds

\begin{tabular}{|c|c|c|c|c|}
\hline Authors & Method & Countries & Time period & Results \\
\hline $\begin{array}{l}\text { Boubaker et } \\
\text { al. }\end{array}$ & $\begin{array}{l}\text { Vector } \\
\text { autoregressive } \\
\text { (VAR) model }\end{array}$ & USA & $\begin{array}{l}\text { January 1998- } \\
\text { December } \\
2013\end{array}$ & $\begin{array}{l}\text { Monetary policy } \\
\text { shocks lead to a } \\
\text { substantial increase } \\
\text { in pension funds' } \\
\text { allocation to equity } \\
\text { assets. }\end{array}$ \\
\hline $\begin{array}{l}\text { Maku, Tella \& } \\
\text { Fagbohun }\end{array}$ & $\begin{array}{lr}\text { Ordinary } & \text { Least } \\
\text { Squares } & \text { (OLS) } \\
\text { model } & \end{array}$ & Nigeria & $1986-2018$ & $\begin{array}{l}\text { Monetary policies } \\
\text { regarding exchange } \\
\text { rate and interest } \\
\text { rate have a direct } \\
\text { influence r on } \\
\text { alleviating poverty. }\end{array}$ \\
\hline Alda & $\begin{array}{lr}\text { Ordinary } & \text { Least } \\
\text { Squares } & (\mathrm{OLS}) \\
\text { model } & \end{array}$ & $\begin{array}{c}13 \text { European } \\
\text { countries }\end{array}$ & $1999-2014$ & $\begin{array}{lr}\text { There is a } & \text { direct } \\
\text { relationship } & \\
\text { between } & \text { equity } \\
\text { pension } & \text { fund } \\
\text { investment } & \text { and } \\
\text { market } & \\
\text { development. } & \end{array}$ \\
\hline $\begin{array}{l}\text { Sievanen, Rita } \\
\& \text { Scholtens }\end{array}$ & $\begin{array}{l}\text { Multinomial } \\
\text { logistic regression }\end{array}$ & $\begin{array}{c}15 \text { European } \\
\text { countries }\end{array}$ & 2010 & $\begin{array}{l}\text { Legal origin of the } \\
\text { country, ownership } \\
\text { of the pension fund } \\
\text { and fund size- } \\
\text { related variables are } \\
\text { associated with } \\
\text { pension funds } \\
\text { responsible } \\
\text { investment. }\end{array}$ \\
\hline
\end{tabular}


Dumiter, F.C., Jimon, S.A., Balteș, N. (2021)

Macroeconomic impact of pension system upon private pension funds scheme. Empirical evidence from Central and Eastern European countries.

\begin{tabular}{|c|c|c|c|c|}
\hline Marcinkiewicz & $\begin{array}{ll}\text { Binary } & \text { logit } \\
\text { regression } & \end{array}$ & Poland & $\begin{array}{l}2011,2013 \\
\text { and } 2015\end{array}$ & $\begin{array}{l}\text { The old-age saving } \\
\text { motive is a } \\
\text { significant predictor } \\
\text { of the size of } \\
\text { savings relative to } \\
\text { household income. }\end{array}$ \\
\hline $\begin{array}{l}\text { Thomas, } \\
\text { Spataro } \\
\text { Mathew }\end{array}$ & $\begin{array}{l}\text { Random }- \text { effects } \\
\text { panel model, Prais- } \\
\text { Winsten regression } \\
\text { with r panel- } \\
\text { corrected standard } \\
\text { errors r and } \\
\text { autoregressive } \\
\text { errors }\end{array}$ & $\begin{array}{l}34 \text { OECD } \\
\text { countries }\end{array}$ & $2000-2010$ & $\begin{array}{l}\text { There is a } \\
\text { significant negative } \\
\text { relationship } \\
\text { between the share } \\
\text { of pension fund } \\
\text { assets invested in } \\
\text { stocks and stock } \\
\text { market volatility in } \\
\text { OECD markets. }\end{array}$ \\
\hline $\begin{array}{l}\text { Aggarwal \& } \\
\text { Goodell }\end{array}$ & $\begin{array}{l}\text { Abnormal Earnings } \\
\text { Growth (AEG) } \\
\text { model } \\
\text { simultaneous panel } \\
\text { regressions }\end{array}$ & 33 countries & 1996-2003 & $\begin{array}{l}\text { Ex-ante equity } \\
\text { premia are larger in } \\
\text { countries that have } \\
\text { a more bank- } \\
\text { oriented financial } \\
\text { architecture, are } \\
\text { wealthier, and have } \\
\text { better governance. }\end{array}$ \\
\hline Nkeki & \begin{tabular}{lr}
\multicolumn{2}{l}{ Hamilton-Jacobi- } \\
Bellman & equation \\
solved r using \\
dynamic \\
programming \\
approach
\end{tabular} & Nigeria & $\begin{array}{l}\text { March } 2006- \\
\text { June 16, } 2016 .\end{array}$ & $\begin{array}{l}\text { Inflation, interest } \\
\text { rate and income } \\
\text { risks have a } \\
\text { significant } \\
\text { influence on the } \\
\text { investor's portfolio } \\
\text { values in the risky } \\
\text { assets. An increase } \\
\text { in income can lead } \\
\text { to an increase in the } \\
\text { portfolio risks and } \\
\text { vice versa. }\end{array}$ \\
\hline
\end{tabular}

Source: Authors' synthesis based on the above-mentioned sources.

The study made by Scharfstein (2018) regarding the effects of pension systems on the financial system shows that there is a negative correlation between the replacement rate of public pension systems and stock market capitalization. The impact of pension reforms on economic growth often presents a lower significance, especially in countries with a higher allocation of the assets of pension funds in 
Dumiter, F.C., Jimon, S.A., Baltes, N. (2021)

Macroeconomic impact of pension system upon private pension funds scheme. Empirical evidence from Central and Eastern European countries.

government bonds (Altiparmakov \& Nedeljkovic, 2016). On the contrary, Been et al. (2017) proved that there is a correlation between private pension funds, income inequality, and poverty in OECD countries, the extent of private pension funds being associated with higher income inequality and increased poverty rate.

Consequently, private savings and pension funds have different socio-economic effects. Nevertheless, private saving is required for a wealth retirement, but the deficient financial knowledge represents a risk for insufficient returns and poverty. The current demographic context of CEEC increased the role of private savings and simultaneous, the need for the development of financial education in order to possess the required financial literacy for proper use of financial concepts and products.

\section{Methodology and model}

The study of macroeconomic effects of pension systems started from the premises that there is a strong connection between the structure of pension systems, the national economy and the development of the financial sector. Therefore, our hypothesis is the followings:

Hypothesis 1: increasing the soundness of investments in financial assets schemes can lead to the strengthening of the public pension system through proper multiplication of resources.

Hypothesis 2: increasing the macroeconomic impact of the pension system by adopting a multistage level of pension system divided into several categories and beneficiaries.

Hypothesis 3: a strong investment strategy of private pension funds can lead to a higher interest rate for deposits under the auspices of the low inflation rate, higher income of the population, and decreasing the severe material deprivation rate.

The empirical study regarding the macroeconomic effects of pension systems in CEEC required the construction of a database composed of financial indicators. Therefore, it was used the statistical data published by Eurostat, OECD, IMF and ECB. The data was extracted from the databases for the time period 2008-2018, in order that all the variables be available for all five CEEC. However, the time period was automatically adjusted by econometric software EViews 10 - University Edition in order to make the sample more significant and relevant statistically, and was set for the period 2009-2018.

The macroeconomic variables considered to be relevant for the empirical study are: - mdENI - median equivalized net income represents the median income of a household, in case all members were equal, available for consumption and savings;

8 Ssciendo

Studia Universitatis "Vasile Goldis" Arad. Economics Series Vol 31 Issue 2/2021 ISSN: 1584-2339; (online) ISSN: 2285 - 3065

Web: publicatii.uvvg.ro/index.php/studiaeconomia. Pages $1-19$ 
Dumiter, F.C., Jimon, Ș.A., Balteș, N. (2021)

Macroeconomic impact of pension system upon private pension funds scheme. Empirical evidence from Central and Eastern European countries.

- psMD - severe material deprivation is the ratio of the population that doesn't have the financial resources needed to purchase the goods and services required for a decent life;

- pINFacp - inflation express the mean percentage change of prices of goods and services purchased by households, compared with the precedent year;

- INTr2 - interest rate for new or renegotiated deposits of households made for a time period of 1-2 years, in national currency;

- EQ - allocation of the assets of private pension funds in equities;

- BB - allocation of the assets of private pension funds in bills and bonds;

- CD - allocation of the assets of private pension funds in cash and deposits;

- OTH - allocation of the assets of private pension funds in other financial titles.

The econometric tests were proceeded with the software EViews 10 University Edition, using pool data regression models. This type of model analyzes the statistical variables bidimensional, by period and cross-section. The most used method is Ordinary Least Squares (OLS), but the method used in this study was Pooled Instrumental Variables (IV) - Two-stage Least Squares (2SLS). 2SLS method has the purpose to establish the predictors correlated with the residuals, named endogenous variables, and replace them with the values estimated through regression with instrumental variables in order to eliminate the endogeneity of independent variables. Instrumental variables define the variables which influence the dependent variable by the effects over the predictors and not by the errors.

The 2SLS method can be used in three forms: standard, with fixed effects, and with random effects. The standard model supposes that there are not present any specific factors to determine the correlation between the predictors and the dependent variable. The model with fixed effects shows the specific individual constant for each country, which explains the differences in the correlation between the variables by the variances of the intercept. The model with random effects highlights the independent random variable which explains the differences between the variables and the variances of the equation errors. To establish the most appropriate model between fixed or random effects 2SLS model will be used the Hausman test to analyze if the errors are correlated with the regressors, the rejection of the null hypothesis suggesting that the use of fixed effects model should be used. For this research, all three methods will be applied for the comparison and the correct interpretation of the empirical results.

The regression equations used in the econometric study are the following:

S sciendo Studia Universitatis "Vasile Goldis" Arad. Economics Series Vol 31 Issue 2/2021 
Dumiter, F.C., Jimon, S.A., Baltes, N. (2021)

Macroeconomic impact of pension system upon private pension funds scheme. Empirical evidence from Central and Eastern European countries.

$$
\begin{aligned}
& I N T r 2_{i t}=\alpha+\beta_{1} \times \operatorname{mdENI}_{i t}+\beta_{2} \times p I N F a c p_{i t}+\beta_{3} \times p s M D_{i t}+ \\
& \beta_{4} \times E Q_{i t}+\beta_{5} \times B B_{i t}+\beta_{6} \times C D_{i t}+\beta_{7} \times O T H_{i t}+\varepsilon_{i t} \\
& I N T r 2_{i t}=\alpha+0,01 \times m d E N I_{i t}+0,50 \times p I N F a c p_{i t}+0,40 \times \\
& p S M D_{i t}+0,07 \times E Q_{i t}+0,05 \times B B_{i t}+0,05 \times C D_{i t}+0,26 \times \\
& O T H_{i t}+\varepsilon_{i t}(1 \mathrm{a}) \\
& I N T r 2_{i t}=\alpha+0,01 \times m d E N I_{i t}+0,43 \times p I N F a c p_{i t}+0,22 \times \\
& p S M D_{i t}-0,09 \times E Q_{i t}-0,13 \times B B_{i t}-0,14 \times C D_{i t}-0,47 \times \\
& O T H_{i t}+\varepsilon_{i t} \quad(1 \mathrm{~b}) \\
& I N T r 2_{i t}=\alpha-0,01 \times m d E N I_{i t}+0,58 \times p I N F a c p_{i t}+0,35 \times \\
& p S M D_{i t}+0,01 \times E Q_{i t}-0,03 \times B B_{i t}-0,08 \times C D_{i t}-0,20 \times \\
& O T H_{i t}+\varepsilon_{i t}
\end{aligned}
$$

Where:

$\alpha$ - free coefficient.

INTr2 - interest rate for bank deposits.

mdENI - median equivalized net income.

pINFacp - inflation.

psMD - severe material deprivation ratio.

$\mathrm{EQ}$ - allocation of the assets of private pension funds in equities.

$\mathrm{BB}$ - allocation of the assets of private pension funds in bills and bonds.

$\mathrm{CD}$ - allocation of the assets of private pension funds in cash and deposits.

$\mathrm{OTH}$ - allocation of the assets of private pension funds in other financial

titles.

$\varepsilon_{i t}-$ regresion error.

\section{Empirical results}

The descriptive analysis of the variables shows, according to the Jarque-Bera test, the normal distribution of the interest rate of the deposits, the allocation of the assets of private pension funds in equities, in bills and bonds, in cash and deposits, and other financial titles, and the anormal distribution of the others variables. Median equivalized net income and the allocation of the assets of private pension funds in bills and bonds present a negative skewness, and the other variables have positive skewness. Kurtosis coefficient highlights the platykurtic distribution of the interest rate of deposits, of the allocation of the assets of private pension funds in equities, in bills and bonds, in cash and deposits and other financial titles, and a leptokurtic distribution of the other variables (Table 2). 
Dumiter, F.C., Jimon, S.A., Baltes, N. (2021)

Macroeconomic impact of pension system upon private pension funds scheme. Empirical evidence from Central and Eastern European countries.

\begin{tabular}{l}
\hline \multicolumn{1}{c}{ Table 2 Descriptive statistics of the econometric model variables } \\
\begin{tabular}{|l|l|l|l|l|l|}
\hline & Mean & Skewness & Kurtosis & Jarque-Bera & Prob. \\
\hline INTr2 & 3.423636 & 1.354175 & 4.268283 & 20.49598 & 0.000035 \\
\hline mdENI & 5276.764 & -0.245555 & 2.159418 & 2.171962 & 0.337570 \\
\hline pINFacp & 2.360400 & 0.379292 & 2.351185 & 2.283440 & 0.319269 \\
\hline psMD & 14.65273 & 0.641209 & 2.169718 & 5.348669 & 0.068953 \\
\hline EQ & 16.21022 & 2.020685 & 6.068998 & 59.01368 & 0.000000 \\
\hline BB & 64.78886 & -1.755041 & 5.778284 & 45.92392 & 0.000000 \\
\hline CD & 9.531344 & 1.434832 & 4.255399 & 22.48354 & 0.000013 \\
\hline OTH & 1.653276 & 1.056604 & 3.581586 & 11.00891 & 0.004069 \\
\hline
\end{tabular}
\end{tabular}

Source: Authors' own processing using the software EViews 10 Academic Edition

The results of the econometric tests of the regression equations by the method Pooled IV-2SLS standard highlight a slight significance of the model (R-squared $=$ 0.79 and Adjusted R-squared $=0.52$ ), but the validity of it, by the perspective of the significance of the coefficients (Prob F-statistic $=0.00$ ). The interest rate is positive correlated with all the predictors, which means that the interest rate of deposits will increase if the median equivalized net income, inflation, severe material deprivation ratio and the allocation of the assets of private pension funds in equities, bills and bonds, cash and deposit and other financial titles increase.

Table 3 The results of the econometric test - Pooled IV - 2SLS standard

\begin{tabular}{|l|l|l|l|}
\hline \multirow{2}{*}{ Variable } & Dependent variable: INTr2 \\
\cline { 2 - 4 } & Coefficient & Std. Error & Prob. \\
\hline C & -14.57140 & 3.672823 & 0.0003 \\
\hline mdENI & 0.001020 & 0.000303 & 0.0016 \\
\hline pINFacp & 0.496981 & 0.100506 & 0.0000 \\
\hline psMD & 0.392476 & 0.069241 & 0.0000 \\
\hline EQ & 0.074657 & 0.022114 & 0.0016 \\
\hline BB & 0.054556 & 0.020623 & 0.0114 \\
\hline CD & 0.048077 & 0.039424 & 0.2295 \\
\hline OTH & 0.259459 & 0.202394 & 0.2069 \\
\hline \hline R-squared & Adjusted R-squared & F-statistic & Prob(F-statistic) \\
\hline 0.787323 & 0.751876 & 24.02661 & 0.000000 \\
\hline
\end{tabular}

Source: Authors' own processing using the software EViews 10 Academic Edition

The correlation matrix of the countries reflects the independence of them and the subunit values of the "r" coefficient (Table 4). The Czech Republic and Slovakia are positively correlated with all other CEEC. Hungary is negatively correlated with Poland but is positively correlated with other countries. Poland is negatively correlated with Hungary and Romania. 
Dumiter, F.C., Jimon, S.A., Balteș, N. (2021)

Macroeconomic impact of pension system upon private pension funds scheme. Empirical evidence from Central and Eastern European countries.

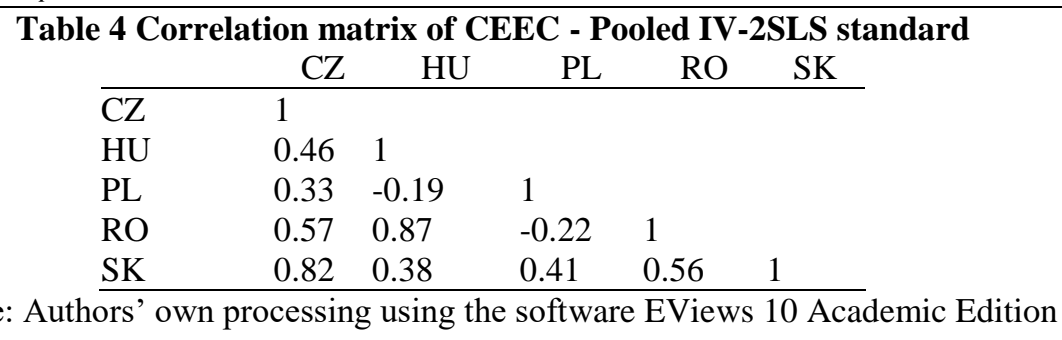

Regarding the residuals of the equation, the Breusch-Pagan LM, Pesaran scaled LM, Bias-corrected scaled LM and the Pesaran CD tests reveal that there is no evidence for the existence of cross-section dependences.

Table 5 Residual Cross-Section Dependence Test

\begin{tabular}{llll} 
Test & Statistic & d.f. & Prob. \\
\hline Breusch-Pagan LM & 36.34358 & 10 & 0.0001 \\
Pesaran scaled LM & 5.890604 & & 0.0000 \\
Bias-corrected scaled LM & 5.612826 & & 0.0000 \\
Pesaran CD & -2.294978 & & 0.0217 \\
\hline
\end{tabular}

Cross-section effects were removed during estimation

Source: Authors' own processing using the software EViews 10 Academic Edition

The study was extended by the method Pooled IV-2SLS with fixed effects. The empirical results show that the model has marginal significance $(\mathrm{R}$-squared $=0.94$ and Adjusted R-squared $=0.89$ ), but is valid regarding the significance of the coefficients $($ Prob F-statistic $=0.00)$.

Table 6 The results of the econometric test - Pooled IV - 2SLS cross-section and period fixed effects

\begin{tabular}{|l|l|l|l|}
\hline \multirow{2}{*}{ Variable } & \multicolumn{3}{|l|}{ Dependent variable: INTr2 } \\
\cline { 2 - 4 } & Coefficient & Std. Error & Prob. \\
\hline C & 6.993577 & 10.09699 & 0.4940 \\
\hline mdENI & 0.000733 & 0.000784 & 0.3577 \\
\hline pINFacp & 0.434705 & 0.134933 & 0.0031 \\
\hline psMD & 0.217949 & 0.064658 & 0.0021 \\
\hline EQ & -0.093252 & 0.075023 & 0.2238 \\
\hline BB & -0.127000 & 0.077733 & 0.1131 \\
\hline CD & -0.139186 & 0.062169 & 0.0330 \\
\hline OTH & -0.471135 & 0.245184 & 0.0645 \\
\hline \hline R-squared & Adjusted R-squared & F-statistic & Prob(F-statistic) \\
\hline 0.935761 & 0.891458 & 20.62814 & 0.000000 \\
\hline
\end{tabular}

Source: Authors' own processing using the software EViews 10 Academic Edition 
Dumiter, F.C., Jimon, Ș.A., Balteș, N. (2021)

Macroeconomic impact of pension system upon private pension funds scheme. Empirical evidence from Central and Eastern European countries.

The influence of the fixed effects led to a positive correlation between the interest rate of the deposits and the median equivalized net income, inflation, and severe material deprivation ratio of the population. Also, the interest rate of deposits is negative correlated with the allocation of the assets of pension funds in equities, bills and bonds, cash and deposits and other financial titles. In other words, the interest rate of deposits will grow if the income of population, inflation and the severe deprivation ratio increase, and if the allocation of assets of private pension funds in financial titles decrease.

The correlation matrix between CEEC reflects a subunit value of the " $r$ " coefficient. The Czech Republic is negatively correlated with Hungary and Romania but is positively correlated with Poland and Slovakia. Hungary is positively correlated with Romania and negatively correlated with other CEEC. Poland is positively correlated only with Czechia and negatively correlated with other CEEC. It is established a positive correlation between Romania and Hungary, between Romania and Slovakia, and between Slovakia and Czechia.

Table 7 Correlation matrix of CEEC - Pooled IV - 2SLS cross-section and period fixed effects

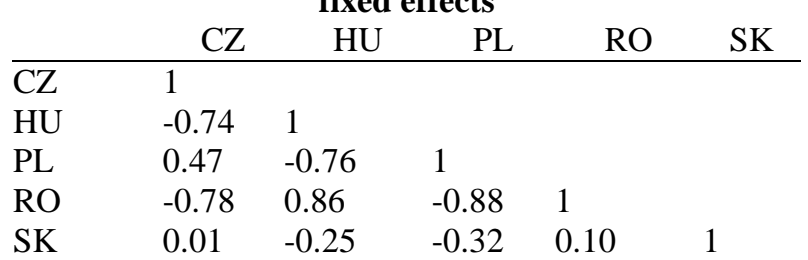

Source: Authors' own processing using the software EViews 10 Academic Edition.

The empirical study can be extended through the analysis of the random effects. According to the Hausman test regarding the random effects, these effects are not correlated with predictors, meaning that the method Pooled IV-2SLS with random effects is more appropriate (Table 7).

Table 8 Correlated Random Effects - Hausman Test

\begin{tabular}{|c|c|c|c|}
\hline Test Summary & Chi-Sq. Statistic & Chi-Sq. d.f. & Prob. \\
\hline Period random & 0.000000 & 7 & 1.0000 \\
\hline * Period test variance i & alid. Hausman sta & ic set to zero. & \\
\hline Period random effects & comparisons: & & \\
\hline Variable & Random & $\operatorname{Var}$ (Diff.) & Prob. \\
\hline $\begin{array}{ll}\text { MDENI? } & 0.000733\end{array}$ & -0.000366 & 0.000000 & 0.0799 \\
\hline PINFACP? 0.434705 & 0.582010 & 0.011385 & 0.1674 \\
\hline 0.217949 & 0.350032 & 0.001571 & 0.0009 \\
\hline
\end{tabular}


Dumiter, F.C., Jimon, S.A., Baltes, N. (2021)

Macroeconomic impact of pension system upon private pension funds scheme. Empirical evidence from Central and Eastern European countries.

\begin{tabular}{lllll} 
EQ? & -0.093252 & 0.004423 & 0.001390 & 0.0088 \\
BB? & -0.127000 & -0.034887 & 0.001691 & 0.0251 \\
CD? & -0.139186 & -0.080488 & 0.001332 & 0.1078 \\
OTH? & -0.471135 & -0.200358 & 0.020224 & 0.0569 \\
\hline
\end{tabular}

Source: Authors' own processing using the software EViews 10 Academic Edition

After applying the method Pooled IV-2SLS with cross-section fixed effects and period random effects, it can be noted that the model has marginal significance ( $\mathrm{R}$ squared $=0.83$ and Adjusted R-squared $=0.80$ ), but it is validated by the significance of the coefficients (Prob F-statistic $=0.00$ ). The empirical results of the tests show the influence of the random effects and the positive correlation between the interest rate of deposits and the inflation, severe material deprivation ratio and allocation of assets of private pension funds in equities. Also, the interest rate is negative correlated with the median equivalized net income and the allocation of assets or private pension funds in bills and bonds, cash and deposits and other financial titles. Therefore, the interest rate of deposits can increase if the inflation and the share of equities in total private pension funds' assets will grow, but also if the income of the population and the allocation of the assets of private pension funds in bills and bonds, cash and deposits and other financial titles will decrease.

Table 9 The results of the econometric test - Pooled IV - 2SLS cross-section fixed effects and period random effects

\begin{tabular}{|l|l|l|l|}
\hline \multirow{2}{*}{ Variable } & \multicolumn{4}{|l|}{ Dependent variable: INTr2 } \\
\cline { 2 - 4 } & Coefficient & Std. Error & Prob. \\
\hline C & 2.173482 & 7.859008 & 0.7836 \\
\hline mdENI & -0.000366 & 0.000470 & 0.4402 \\
\hline pINFacp & 0.582010 & 0.082596 & 0.0000 \\
\hline psMD & 0.350032 & 0.051083 & 0.0000 \\
\hline EQ & 0.004423 & 0.065100 & 0.9462 \\
\hline BB & -0.034887 & 0.065963 & 0.6000 \\
\hline CD & -0.080488 & 0.050328 & 0.1180 \\
\hline OTH & -0.200358 & 0.199727 & 0.3221 \\
\hline \hline R-squared & Adjusted R-squared & F-statistic & Prob(F-statistic) \\
\hline 0.829067 & 0.779586 & 18.21570 & 0.000000 \\
\hline
\end{tabular}

Source: Authors' own processing using the software EViews 10 Academic Edition

The correlation matrix of the CEEC reflects the independence of them and subunit values of the " $r$ " coefficient. Czech Republic is positively correlated with all CEEC. Hungary is negatively correlated only with Poland, being positively 
Dumiter, F.C., Jimon, Ș.A., Balteș, N. (2021)

Macroeconomic impact of pension system upon private pension funds scheme. Empirical evidence from Central and Eastern European countries.

correlated with the other three CEEC. Poland is positively correlated only with Czechia, and with other CEEC is negatively correlated. Romania and Slovakia have a negative correlation only with Poland, establishing a positive correlation with all other CEEC.

Table 10 Correlation matrix of CEEC - Pooled IV - 2SLS cross-section fixed effects and period random effects

\begin{tabular}{|c|c|c|c|c|c|}
\hline & $\mathrm{CZ}$ & $\mathrm{HU}$ & $\mathrm{PL}$ & $\mathrm{RO}$ & SK \\
\hline$\overline{\overline{\mathrm{CZ}}}$ & 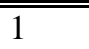 & & & & \\
\hline $\mathrm{HU}$ & 0.62 & 1 & & & \\
\hline PL & 0.12 & -0.24 & 1 & & \\
\hline RO & 0.51 & 0.94 & -0.40 & 1 & \\
\hline SK & 0.33 & 0.51 & -0.26 & 0.58 & 1 \\
\hline
\end{tabular}

Source: Authors' own processing using the software EViews 10 Academic Edition

\section{Conclusion and final discussions}

In Central and Eastern European countries, the national pension systems were updated to meet the multi-pillar structure proposed by World Bank. This restructuring allowed the states to outsource some of the demographic pressure from the public pension systems through private pension funds. However, the large expenditure of the public pension system, increased burden of social contribution of current employees and the negative rate of return of private pension funds lead to the minimalization of mandatory private pension funds in CEEC.

Nowadays in the demographic and socio-economic context, private savings and private pension funds represent a requirement for ensuring wealth at retirement. Increased responsibility of the population in ensuring the needed incomes at retirement represents an opportunity to develop the stock markets and stimulate the competitiveness of the financial sector, but also to decrease poverty. At the same time, financial literacy and knowledge of the population must be increased for the correct use of financial concepts and products.

The empirical study of macroeconomic effects of pension systems started from the premises that there is a strong connection between the structure of pension systems, the national economy and the development of the financial sector. Using the statistical data published by Eurostat, OCDE, IMF and ECB for the period 20092018, it was employed a regressive analysis by the method Pooled IV-2SLS. Applying both Pooled IV-2SLS standard, with fixed effects and random effects, the results present more relevant outcomes in case of cross-section and period fixed effects due to the catching of the specific features of all five CEEC and each time period. 
Dumiter, F.C., Jimon, S.A., Baltes, N. (2021)

Macroeconomic impact of pension system upon private pension funds scheme. Empirical evidence from Central and Eastern European countries.

An important role in maintaining an adequate financial flow at retirement is given by the capacity of savings during working life. In this regard, the econometric study highlights that the interest rate at deposits increases if the incomes of the population rise, in an inflationist climate and by growing the severe material deprivation rate. Indeed, the reduced economic resources lead to a high price of them, and in our case, the small amount of financial resources will lead to the increase of interest rate for deposits. Moreover, the most used instrument of central banks to maintain price stability is the interest rate, which in a period with high inflation will be increased. However, the sustainable development of a country cannot be made in conditions of hyperinflation and low levels of income.

The interest rate of deposits is affected by the investment strategy of private pension funds, the increasing of the financial assets of the pension funds leading to the decrease of interest rate of deposits. This correlation reflects the competitivity between personal saving through the banking sector and private pension funds. Personal savings should be diversified between different types of financial assets with different exposure to investment risks. Therefore, in CEEC must be increased the financial literacy and the financial inclusion, but also the financial instruments should be better promoted. Moreover, personal savings should be stimulated by tax deductions and exemptions.

The results confirmed the hypotheses of the study and the conclusion is that there is indeed a correlation between the interest rate of deposits, the amount of income earned by population, inflation rate, severe material deprivation of population and allocation of assets of private pension funds.

\section{Acknowledgments}

The authors thank the anonymous reviewers and editor for their valuable contribution.

\section{Funding}

This research received no specific grant from any funding agency in the public, commercial, or not-for-profit sectors.

\section{Author Contributions}

The authors contributed equally to this work.

\section{Disclosure Statement}

The authors have not any competing financial, professional, or personal interests from other parties. 
Dumiter, F.C., Jimon, Ș.A., Balteș, N. (2021)

Macroeconomic impact of pension system upon private pension funds scheme. Empirical evidence from Central and Eastern European countries.

\section{References}

1. Aggarwal, R., Goodell, G.W., (2011), International variations in expected equity premia: Role of financial architecture and governance, Journal of Banking \& Finance, vol. 35, pp. 3090-3100

2. Alda, M., (2017), The relationship between pension funds and the stock market: Does the aging population of Europe affect it? International Review of Financial Analysis, vol. 49, pp. 83-97

3. Almenberg, J., Dreber, A., (2015), Gender, stock market participation and financial literacy, Economics Letters, vol. 137, pp. 140-142

4. Altiparmakov, N., Nedeljkovic, M., (2016), Does Pension Privatization Increase Economic Growth? Evidence from Latin America and Eastern Europe, CESIFO Working Paper no. 6074

5. Anderson, A., Baker, F., Robinson, D.T., (2017), Precautionary savings, retirement planning and misperceptions of financial literacy, Journal of Financial Economics, vol. 126, pp. 383-398

6. Apouey, B.H., (2018), Preparation for old age in France: The roles of preferences and expectations, The Journal of the Economics of Ageing, vol. 12, pp. 15-23

7. Been, J., Caminada, K., Goudswaard, K., van Vliet. O., (2017), Public/Private Pension Mix, Income Inequality and Poverty among the Elderly in Europe: An Empirical Analysis Using New and Revised OECD Data, Social Policy \& Administration, vol. 51(7), pp. 1079-1100

8. Berk, A.S., Cok, M., Kosak, M., Sambt, J., (2013), CEE Transition from PAYG to Private Pensions: Income Gaps and Asset Allocation, Czech Journal of Economics and Finance, vol. 63(4), pp. 360-381

9. BNR, (2018), Raport asupra stabilității financiare, Banca Națională a României, București

10. Boubaker, S., Gounopoulos, D., Nguyen, D.K., Paltalidis, N., (2017), Assessing the effects of unconventional monetary policy and low-interest rates on pension fund risk incentives, Journal of Banking and Finance, vol. 77, pp. 35-52

11. Dushi, I., Iams, H.M., Tamborini, C.R., (2017), Contributory Retirement Saving Plans: Differences Across Earnings Groups and Implications for Retirement Security, Social Security Bulletin, vol. 77(2), pp. 13-24

12. Eatock, D., (2015), European Union pension systems Adequate and sustainable?, European Parliamentary Research Service

13. European Commission-Directorate-General for Employment, Social Affairs and Inclusion, (2018), The 2018 Pension Adequacy Report: current and future income adequacy in old age in the EU, Vol.I, Publications Office of the European Union, Luxembourg

14. Gallo, G., Torricelli, C., van Soest, A., (2018), Individual heterogeneity and pension choices: Evidence from Italy, Journal of Economic Behavior and Organization, vol. 148, pp. 260-281

15. Gerardi, K., Goette, L., Meier, S., (2013), Numerical ability predicts mortgage default, Proceedings of the National Academy of Sciences, vol. 110, pp. 11267-11271 
Dumiter, F.C., Jimon, S.A., Baltes, N. (2021)

Macroeconomic impact of pension system upon private pension funds scheme. Empirical evidence from Central and Eastern European countries.

16. Gerrans, P., Moulang, C., Feng, J., Strydom, M., (2018), Individual and peer effects in retirement savings investment choices, Pacific-Basin Finance Journal, vol. 47(C), pp. 150165

17. Grech, A.G., (2014), Pension policy design: The core issues, MPRA Paper No. 53662. Available online at http://mpra.ub.uni-muenchen.de/53662/.

18. Gustafson, M.T., (2017), The market sensitivity of retirement and defined contribution pensions: Evidence from the public sector, Journal of Public Economics, vol. 145, pp. 1-13 19. Hasler, A., Lusardi, A., Oggero, N., (2018), Financial fragility in the US: Evidence and implications, Global Financial Literacy Excellence Center, The George Washington University School of Business

20. Kurtbegu, E., (2018), Replicating intergenerational longevity risk sharing in collectively defined contribution pension plans using financial markets, Insurance: Mathematics and Economics, vol. 78, pp. 286-300

21. Lusardi, A., Mitchell, O.S., (2014), The economic importance of financial literacy: Theory and evidence, Journal of Economic Literature, vol. 52, pp. 5-44

22. Majid, M.S.A.M., Dewi, S., Aliasuddin, Kassim, S.H., (2019), Does Financial Development Reduce Poverty? Empirical Evidence from Indonesia, Journal of Knowledge Economy, vol. 10, pp. 1019-1036

23. Maku, O.E., Tella, A.T., Fagbohun, A.C., (2020), Alleviating poverty in Nigeria: Keynesian vs monetary theory of poverty, Studia Universitatis "Vasile Goldis" Arad. Economics Series, vol. 30(1), pp. $103-120$

24. Marcinkiewicz, E., (2018), Does the retirement saving motive foster higher savings? The evidence from the Polish household survey, Business and Economic Horizons, vol. 14 (1), pp. 85-96

25. Marin, A.G., Schwabe, R., (2019), Bank Competition and Financial Inclusion: Evidence from Mexico, Review of Industrial Organization, vol. 55, pp. 257-285

26. Metzger, C., (2018), Intra-household allocation of non-mandatory retirement savings, The Journal of the Economics of Ageing, vol. 12, pp. 77-87

27. Mihailovs, J., Kreituss, I., (2015), Optimal Risk/Return Trade-Off of the $2^{\text {nd }}$ Pillar Pension Plans in Latvia, Journal of Business Management, vol. 9, pp. 74-86

28. Nkeki, C.I., (2018), Optimal pension fund management in a jump-diffusion environment: Theoretical and empirical studies, Journal of Computational and Applied Mathematics, vol. 330, pp. 228-252

29. OECD, (2017), G20/OECD INFE report on adult financial literacy in G20 countries, OECD Publishing

30. OECD, (2019), Pension Markets in Focus, OECD Publishing, Paris. Available online at https://www.oecd.org/finance/private-pensions/pensionmarketsinfocus.htm

31. Rey-Ares, L., Fernandez-Lopez, S., Vivel-Bua, M., (2018), The Influence of Social Models on Retirement Savings: Evidence for European Countries, Social Indicators Research, vol. 136, pp. 247-268

32. Scharfstein, D., (2018), Pension Policy and the Financial System, The Journal of Finance, vol. LXXIII (4), pp. 1463-1512 
Dumiter, F.C., Jimon, Ș.A., Balteș, N. (2021)

Macroeconomic impact of pension system upon private pension funds scheme. Empirical evidence from Central and Eastern European countries.

33. Schneider, O., (2009), Reforming Pensions in Europe: Economic Fundamentals and Political Factors, Czech Journal of Economics and Finance, vol. 59(4), pp. 292-308

34. Sievanen, R., Rita, H., Scholtens, B., (2013), The Drivers of Responsible Investment: The Case of European Pension Funds, Journal of Business Ethics, vol. 117, pp. 137-151

35. Thomas, A., Spataro, L., Mathew, N., (2014), Pension funds and stock market volatility: An empirical analysis of OECD countries, Journal of Financial Stability, vol. 11, pp. 92-103

36. Wang, X., Williamson, J.B., Cansoy, M., (2016), Developing countries and systemic pension reforms: Reflections on some emerging problems, International Social Security Review, vol. 69(2), pp. 85-106

37. Zeng, Y., Li, D., Chen, Z., Yang, Z., (2018), Ambiguity aversion and optimal derivative-based pension investment with stochastic income and volatility, Journal of Economic Dynamics \& Control, vol. 88, pp. 70-103 